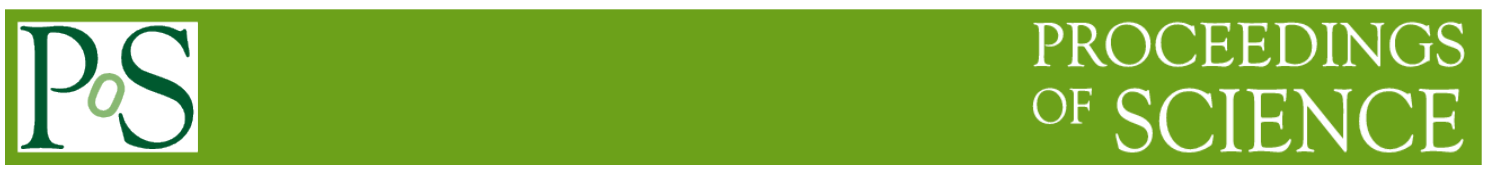

\title{
Antecedents of Project Success in Donation-based Crowdfunding-based on Tencent LeJuan Platform in China
}

\author{
Ying Qian \\ Shanghai University \\ Shanghai, 200000, China \\ E-mail: qian.yinget.shu.edu.cn \\ Jiang Lin ${ }^{1}$ \\ Shanghai University \\ Shanghai, 200000, China \\ E-mail: $1779726827 @ q q$. com
}

\begin{abstract}
As a new model for funding charity projects, the donation-based crowdfunding uses Internet to raise money from public in a more transparent and supportive way. It stimulates the development of philanthropy in China. However, few studies have investigated factors affect the success of such projects, even though it plays an important role in the growth of donation-based crowdfunding. Based on the elaboration likelihood model (ELM), the paper empirically analyzed the factors influencing the fund-raising result. Data from the donation-based crowdfunding platform-Tencent Lejuan, was collected and analyzed. The results showed that the founders' credibility significantly impacts the projects financing ratio. Besides, for project description, pictures help to raise public awareness of the charity projects to improve the likelihood of project success. But too many words reduce donors' intention to donate. Last but not the least, projects with target amountmultiple goals encounter difficulties to succeed.
\end{abstract}

ISCC 2017

16-17 December 2017

Guangzhou, China

${ }^{1}$ Speaker 


\section{Introduction}

Donation-based crowdfunding is a new type of charitable fund-raising model, where philanthropic projects directly attract donors on the internet. Donation-based crowdfunding has a low threshold for the public to participate in philanthropic project and generates diverse, creative projects. Therefore, this new type of fund-raising model corresponds to the development of philanthropy in China. The philanthropy in China is undertaking reform to reduce intermediary and information asymmetry. The donation-based projects are subject to the public inspection on the open market. It is an effective way to propagate philanthropic ideas and rules [1]. China's donation-based crowdfunding size reached 12.72 million yuan in 2014 [2], 34.22 million yuan in 2015, with an increase of $170 \%$ in a year. Compared with 2014, the number of projects increased by $192 \%$, and the number of backers had a growth of $68 \%$. The average amount of donation per individual backer is 57 yuan, $61 \%$ higher than 2014 . However, the amount of charitable crowdfunding projects in China is only about $1 \%$ of the total amount of Internet donations, and donation-based crowdfunding is yet to be developed. Therefore, it is of great importance to study the factors influencing the financial performance of donation-based crowdfunding projects, to boost the projects to obtain more donations and to make crowdfunding industry develop efficiently.

\section{Literature Review}

As a new charitable fundraising model, the research of donation-based crowdfunding is still limited. Smith et al. analyzed the data sets on JustGiving and Virgin Money, and found that there was a positive peer effect, that is, the donor's reference to the information donated by others to decide which items they should donate [3]. Koning et al. found that the amount of donations received at the beginning of the project would affect the donor's subsequent donation and had a significant impact on the success of the project [4]. Kuppuswamy et al. found that donor support for the project was in line with the U-model, which would lead to more donor support at the beginning and the end of the project fundraising [5]. Katherine Choy et al. studied the "Earthship Kapita", a third world aid project for Chuffed, a public service platform, the results showed that donors usually express their support for the event, and through online social media and oral transmission to their families and friends, to attract more people to support the project [6].

Donation-based crowdfunding has the same structure or framework as other types of crowdfunding (reward-based, lending-based orequity-based crowdfunding). Therefore, we can refer to previous investigation on the antecedents of successful crowdfunding projects. Mollick argues that personal networks and potential project quality are related to the success of project finance. He also pointed out that the project financing duration negatively affect the financing success rate, because longer period of investment will reduce enthusiasm for the investment [7]. Many researchers found that the impact of the target amount on financial performance on project success rate is negative [8-12]. Some found that the impact of the number of projects initiated and updates on financial performance has positive effects $[8,10]$. Other researchers found that comments on project success rate is important for project success. [8,9,12]. Zheng et al. analyzed the performance of the financing project from the shareholders' information and the project valuation [13]. Huang et al. analyzed the factors influencing the success of the 
projects based on the customer value transference theory from the aspects of product value, personnel value, service value and image value [14]. Wu et al. investigated the factors influencing the success of the project, such as the amount of concerns on projects, the interaction of the project, the price gradient of the project and the form of the project organization in the presence of herding, they also pointed out that products were developed in the process of project financing [15]. Chen et al. analyzed the equity-based projects based on signal theory and herding theory [16]. Zheng et al. demonstrated that the better the credit record of the sponsor is, the higher the performance of the project financing would be; the structured social capital accumulated by the sponsors in the community will improve the financial performance of the project; the higher the relational social capital formed by the promoters' interaction with others during project financing, the higher the performance of project financing [17]. Table 1 shows the factors of the crowdfunding projects presented by researchers.

\begin{tabular}{|c|c|}
\hline Reference & Factors \\
\hline Mollick E R (2013) & Project quality, personal social network, financing duration \\
\hline $\begin{array}{l}\text { Moutinho N and Leite PM } \\
(2013)\end{array}$ & $\begin{array}{l}\text { Target amount, supporters, comments, updates, reward levels, } \\
\text { the number of projects initiated }\end{array}$ \\
\hline $\begin{array}{l}\text { Quercia D and Crowcroft J } \\
(2014)\end{array}$ & $\begin{array}{l}\text { Target amount, the number of friends in personal social } \\
\text { network, comments, supporters, the financing duration }\end{array}$ \\
\hline Lu CT et al. (2014) & $\begin{array}{c}\text { Target amount, updates, the number of projects initiated and } \\
\text { supported, supporters }\end{array}$ \\
\hline Frydrych D et al. (2014) & Target amount, supporters, financing duration \\
\hline Cumming DJ et al. (2014) & $\begin{array}{c}\text { Target amount, reward levels, updates, social network, } \\
\text { comments, supporters }\end{array}$ \\
\hline Zheng et al. (2015) & Updates, financing duration, team size \\
\hline Huang et al. (2015) & $\begin{array}{c}\text { Target amount, reward levels, team size, the number of } \\
\text { projects initiated, shares, comments, images }\end{array}$ \\
\hline Wu et al. (2016) & Followers, comments, financing duration, team size \\
\hline Chen et al. (2016) & Target amount, team size \\
\hline Zheng et al. (2015) & The full text, the number of projects failed, social network \\
\hline
\end{tabular}

Table1: Factors in References

\section{Thoery and Hypothesis}

\subsection{ELM Thoery}

ELM (Elaboration Likelihood Model) model is a dual channel theory that studies the perception and behaviour of human beings [18]. ELM argues that there are two ways to convey information to humans: one is called Central Route, and the other Peripheral Cues. Central Route is a direct transmission of information, such as the detailed product parameters. Peripheral Cues does not directly provide product information, but provides relevant perceptual materials, such as the reliability of products supplier and the degree of attractiveness. The Central Route requires more cognitive efforts on information reception, detailed information analysis, while the Peripheral Cues don't require much thought [19].

For donation-based crowdfunding, we take the project quality as Central Route. We use the full text, the number of pictures, the target amount as a measure of the project quality. Previous studies on online trust construction found that the Peripheral Cues includes: response rate, page design, web quality, picture quality, and information availability of the sponsor [20]. 
Thus, this paper analyses the credit of the sponsor and the supervisor as Peripheral Cues. In this paper, the financial performance is evaluated by the rate of financing.

\subsection{Research Hypothesiss}

\subsubsection{Central Route-Project Quality}

There are information asymmetry problems in crowdfunding project, and it is difficult for donors to evaluate the quality of crowdfunding projects. Donors perceive the quality of charitable projects by browsing the web information. Project initiators provide detailed information to reduce the information asymmetry [21]. Zheng et al. used the project text as a measure of the quality variables [17]. Huang et al. believed that more pictures can bring investors more intuitive cognition and experience [14]. Thus, we select the number of words and the number of images in the project description to measure the quality of crowdfunding projects. The number of videos is not considered as very few project has vedios now. Project target amount is also a reflection of the project quality. Huang et al. took the scale of the project's target-raising as a product value [14]. Larger target amount leads to higher requirement for project quality and more difficult to attract investors. The following assumptions are made:

H1: The number of words of the project positively affect the project financial ratio.

$\mathrm{H} 2$ : The number of pictures of the project positively affect the project financial ratio.

H3: The project target amount negatively affect project financial ratio.

\subsubsection{Peripheral Cues-Social Capital}

Trust and trust-building mechanisms are important in internet finance because they can reduce the perceived uncertainty and the risks associated with anonymous transactions on the internet [20]. Song and Han indicated that the trust variable is the most important factor affecting the willingness of the investor to lend, based on PaiPaiDai data [22]. The results showed that trust between the borrowers and investors, and the investors' trust in the intermediary is an important factor influencing their investment intention. The information of the initiators of crowdfunding projects is limited, and the credit and execution capacity of the initiators is evaluated mainly by measuring the number of charitable projects initiated and supported in the past. Martina and Wang found that borrowers' past experience in P2P helped to improve their borrowing completion probability [23]. Similarly, we suggested that the project initiators' previous performance on crowdfunding platform will affect project success chance:

H4: The more number of projects initiated, the higher the project financial ratio.

H5: The more number of projects supported, the higher the project financial ratio.

\section{Research Design}

\subsection{Variable Design}

The financial ratio is a common indicator in researches on crowdfunding performance. For example, Chen et al. used financial ratio to measure the performance of equity-based crowdfunding [16]. Similarly, this paper chooses financial ratio as a performance index.

In addition, all the fundraising has financing duration. Zheng et al. found that the longer the financing duration, the worse the financial performance [17]. Therefore, we believe that the financial duration will affect the outcome of donation-based crowdfunding. The financial duration is set as a control variable. The variables in this study are designed as follows: 


\begin{tabular}{|c|c|c|}
\hline Variable & Type & Description \\
\hline The full text & integer & $\begin{array}{l}\text { Describe the number of words in the comprehensive } \\
\text { project information, like what, why, how. }\end{array}$ \\
\hline The number of pictures & integer & $\begin{array}{l}\text { The number of pictures used in the project } \\
\text { description. }\end{array}$ \\
\hline Target amount & float & $\begin{array}{c}\text { The amount project initiator seeks to raise via } \\
\text { crowdfunding. }\end{array}$ \\
\hline $\begin{array}{l}\text { The number of projects } \\
\text { initiated }\end{array}$ & integer & $\begin{array}{l}\text { The number of projects initiated by the project } \\
\text { initiator on the platform. }\end{array}$ \\
\hline $\begin{array}{l}\text { The number of projects } \\
\text { supported }\end{array}$ & integer & $\begin{array}{c}\text { The number of projects historically supported by the } \\
\text { project supervisors on the platform, like charity } \\
\text { organizations. }\end{array}$ \\
\hline The duration & integer & Refers to the pre-set duration of project financing. \\
\hline The financial ratio & float & $\begin{array}{l}\text { The ratio of the amount of donation to the target } \\
\text { amounttarget amount. }\end{array}$ \\
\hline
\end{tabular}

Table2:Description of Variables

\subsection{Dataset}

At present, many crowdfunding platforms have donation-based crowdfunding projects, we chose Tencent Lejuan (www.gongyi.qq.com ) platform for data collecation because the platform is purely charitable crowdfunding platform, which has a large number of charitable projects, and has a great influence in on charitable crowdfunding platforms. On Lejuan platform, the project initiator is separated from the project supervisor. The project initiator is responsible for initiating and executing the project, however, the supervisor is responsible for supervising the whereabouts of the money and issuing the relevant certificates and invoices. Project initiator can be individuals, foundations, or charitable charity organizations and or other institutions, while project supervisor is usually charity foundations or organizations. We collected the information of 922 completed projects from April 2016 to May 2016. Among them, 419 projects reached equal to or more than $100 \%$ financialng ratio. Thus, the success rate is $45.44 \%$. Descriptive statistics for these projects are shown in table 3.

\begin{tabular}{|c|c|c|c|c|}
\hline Variable & Mean & Std. Dev. & Min. & Max. \\
\hline The full text & 2545.50 & 1045.38 & 741.00 & 9799.00 \\
\hline The numbers of picturesimages & 13.03 & 9.90 & 1.00 & 84.00 \\
\hline Goal amount & 111682.14 & 278499.37 & 665.00 & $\begin{array}{c}6000000 . \\
00\end{array}$ \\
\hline $\begin{array}{c}\text { The numbers of projects initiated } \\
\text { The numbers of projects got } \\
\text { supported }\end{array}$ & 67.07 & 125.47 & 1.00 & 548.00 \\
\hline The duration & 50.73 & 327.52 & 1.00 & 1064.00 \\
\hline The financing ratio & 0.59 & 43.38 & 1.00 & 275.00 \\
\hline
\end{tabular}

Table 3: Summary Statistics

\section{Result}

In this paper, multiple regression analysis is used to test hypothesis. To explore whether the regression results are reliable, the a robust test is was made conducted on for the estimation estimated results. The variance expansion factor of all variables is less than 2 , indicating that there is no multi-collinearity problem in the independent variables. Regression results are shown in Table 4. The model explains the variance of the financialing ratio of $52.8 \%$ (adjusted $\mathrm{R}$ 
square $52.5 \%$ ). According to table 4 , the results of model show that, in terms of project quality, we found that the full text of project descriptive information description is negatively related with to the financialng ratio $(\mathrm{P}=0.038<0.05)$. $\mathrm{H} 1 \mathrm{has}$ not been verified. Nevertheless, the number of images pictures in the detailed project description of the project has a positive impact on the financing financial performance $(\mathrm{P}=0.000<0.001)$. The goal amount has a negative impact on the financialng performance $(\mathrm{P}=0.000<0.001)$. The results reflect that for the donors who directly choose the Central Route to make decisions, the long description text or the large goal amount will result in unfavourable elaboration processing and less investment. On the contrary, the application of more images pictures has a positive influence on donation decisionmaking, because it not only could reduce donors' confusion, but also could show initiators' active attitudes for towards solving the problem of information asymmetry. The results prove the $\mathrm{H} 2$ and $\mathrm{H} 3$. And the numbers of projects initiated and the numbers of projects supported have a positive impact on the financing performance $(\mathrm{P}=0.004<0.05, \mathrm{P}=0.000<0.001)$. The results reflect that the Peripheral Clues provided by initiators will contribute significantly in donation decision-making. Initiators and supervisors build their own social capital in the internal community by interacting with donors, sponsors and as well as donating for or supporting other projects, which will promote the successful success of the financing of this project. H4 and H5 are proved. Finally, we found that the impact of control variables on financialng performance is also significantly negative: long financing duration have negative influence on financing ratio, which is similar with the previous research results.

\begin{tabular}{|c|c|c|c|}
\hline Hypothesi & IV & \multicolumn{2}{|c|}{ Financialng Ratio } \\
\cline { 3 - 4 } s & & Coefficient & P Value \\
\hline H1 & The full text & $-2.536 \mathrm{E}-05$ & $.038^{*}$ \\
\hline H2 & The nNumbers of images & $1.008 \mathrm{e}-02$ & $.000^{* * *}$ \\
\hline H3 & Goal amountThe target amount & $-1.545 \mathrm{e}-7$ & $.000^{* * *}$ \\
\hline H4 & The numbers of projects initiated & $2.600 \mathrm{e}-04$ & $.004^{* *}$ \\
\hline H5 & The numbers of projects supported & $1.949 \mathrm{e}-04$ & $.000^{* * *}$ \\
\hline R square & & \multicolumn{2}{|c|}{0.528} \\
\hline $\begin{array}{c}\text { Adjusted R } \\
\text { Square }\end{array}$ & & \multicolumn{2}{|c|}{0.525} \\
\hline
\end{tabular}

*significant at 0.05 level; **significant at 0.01 level; ***significant at 0.001 level.

Table 4: Multiple Regression Hypothesis Test Results

\section{Conclusion}

\subsection{Discussion}

Based on the ELM theory, this paper investigated the influencing factors of the financing performance of donation-based crowdfunding projects. The data from Tencent Lejuan network was adopted to tests hypothesis. The main results are discussed as follows:

Firstly, we found that the full text of project description has a negative impact on the financing performance. Donors may be reluctant to spend too much time and energy to read through the text, and too much redundant narration would reduce public intention of donation. At the same time, we also found that the number of images pictures placed in the project description session has significant positive effect for the financing performance. The Pictures are intuitive and credible description of the project, so more images can improve the donors' perception of the project quality. In addition, the target amount has a significant negative impact 
on financing performance. Possible reasons are that when the target amount is set too high, the donor will psychologically hesitate about whether the project really needs that amount. If it does not meet the donor's expectations, it will reduce the perceived project quality.

Secondly, the number of projects initiated and the number of projects supported have a significant positive impacts on financing performance in donation-based crowdfunding. Donors may think that the project initiators and the project supervisors are trustworthy, and will be more convinced to contribute to such projects. At present, crowdfunding platform do not force the project initiators to publish personal information such as their economic situation by crowdfunding platforms. It is somehow difficult for the donors to judge whether the project is credible with information asymmetry. The credit of the initiator is evaluated based on the number of historically launched projects and the number of projects supported. Thus, these numbers will be important in determining whether the project can be successful or not.

Thirdly, regarding the control variables, this paper found that the funding duration has a negative impact on funding performance. In the field of donation-based crowdfunding, the demand for funds are usually very urgent. Therefore, a reasonable funding duration would allow donors to perceive the urgency of funding needs, and attract more donors.

Above all, the results show that donors tend to take the Central Route to elaborate processing and refer to Peripheral Clues to make decisions. The donors with weaker cognitive ability and less relevant knowledge will pay more attention to peripheral information apart from project descriptive information. The social capital that initiators built in the internal community will stimulate the success of financing.

\subsection{Contribution}

The theoretical contributions is that based on the ELM theoretical structure, the paper analyzes the impact of initiators' credibility and project quality on financing performance.

The practical significance of this paper lies in two points: 1) for the donation-based crowdfunding platforms, they should constantly improve the initiators' credit evaluation mechanism. Not only should the platform show the number of historically launched projects and historical projected supported, but also should provide other personal information so that donors could measure their credit level. If the initiators are individuals, the platform can show the credit level on the webpage. If the initiators are foundations, charity or other organizations, the platform can rate their business history. 2) For project initiators and supervisors, initiators should provide personal information, and supervisor should offer some official certification. At the same time, when the project initiators initiate a project, the full text described in the project details should be concise with more pictures, the goal amount should be at a reasonable level for the purpose of project promotion.

\subsection{Limitation}

The paper has several aspects to improve. One is that the data mentioned of in this paper comes from Tencent Lejuan platform. Although the platform is a China's well-known donationbased crowdfunding site, there are limitations, such as, there is no interaction of project initiators and donors. The impact of interaction can not be studied. Follow-up scholars can analyze on other charitable platforms data and are welcomed to expand the model to verify this point. Another is that no video information is considered right now as very few projects provide video on Lejuan. The third is that the social capital of Tencent Lejuan platform was not included 
in this paper. Many scholars have suggested that both the structural social capital and, or social media in the third party have an impact on crowdfunding performance. Therefore, follow-up scholars can collect relevant data to investigate the social network effect of platforms.

\section{References}

[1] Internet Financial Innovation and Supervision Sichuan Province Collaborative Innovation Center. China 's Donation-based Crowdfunding Development Report 2015[R](2016) (In Chinese)

[2] Richardson Consultant. Zhongchou Platform. China's Donation-based Crowdfunding Development Report 2014[R] (2015) (In Chinese)

[3] S. Smith, F. Windmeijer, E. Wright. Peer Effects in Charitable Giving: Evidence from the (Running) Field [J]. Economic Journal, 125(585):1053-1071(2015)

[4] R. Koning, J. Model. Experimental Study of Crowdfunding Cascades: When Nothing Is Better than Something. Academy of Management Proceedings(2014)

[5] V. Kuppuswamy, BL. Bayus. Crowdfunding Creative Ideas: The Dynamics of Project Backers in Kickstarter[J]. Ssrn Electronic Journal(2013)

[6] D. Schlagwein, K. Choy. IT Affordances and Donor Motivations in Charitable Crowdfunding: The "Earthship Kapita” Case[C]. European Conference on Information Systems(2015)

[7] E.R. Mollick. The dynamics of Crowdfunding: determinants of success and failure[J].29(1):116(2013)

[8] N. Moutinho, P.M. Leite. Critical success factors in crowdfunding: the case of Kickstarter [EB/OL]. Http://repositorioaberto.up.pt/handle/10216/71581(2013)

[9] D. Quercia, J. Crowcroft. Recommending investors for crowdfunding project [C]. In Proceedings of the 23 rd International Conference, April (2014)

[10] C.T. Lu, S. Xie, X. Kong, P.S. Yu. Infer the impacts of social media on crowdfunding [C]. Proceedings of the 7th ACM International Conference (2014)

[11] D. Frydrych, AJ. Bock, T. Kinder, B. Koech, et al. Exploring Entrepreneurial Legitimacy in rewardbased Crowdfunding [J]. Venture Capital,16 (3):247-269(2014)

[12] D.J. Cumming, G. Leboeuf, A.Schwienbacher. Crowdfunding Models: Keep-it-All vs. All-orNothing. http://ssrn.com/abstract=2447567(2014)

[13] H.C. Zheng, Y.M. Huang, T. Wang, D.Y. Chen. Antecedents of Equity-based Crowdfunding Success for Innovation Projects[J]. China Soft Science, PP:130-138(2015) (In Chinese)

[14] J.Q. Huang, H. Chen, D.Y. Li. Research on Factors Influencing the Success of Crowd Funding Projects: the Perspective of Customer Value. China Soft Science, PP:116-127(2015) (In Chinese)

[15] W.Q. Wu, M.X. Fu, L.M. Zhao. Successful Factors and Herding Phenomenon of Crowdfunding[J]. Soft Science, PP:5-8(2016) (In Chinese)

[16] L. Chen, M.Y. Yu. Empirical Analysis on Influence Factors of Funding Performance of Equity Crowdfunding Projects [J]. Journal of Shandong Agricultural University(Natural Science Edition), 47(4):000-000(2016) (In Chinese)

[17] H.C. Zheng, Z.H. Qi, J. Wu, T. Wang, N. Wan. Antecedents of Award-Based Crowdfunding Performance From the ELM Perspective[J]. Journal of University of Electronic Science and Technology of China(Social Sciences Edition), PP:45-50(2015) (In Chinese) 
[18] R.E. Petty, J.T. Cacioppo. The elaboration likelihood model of persuasion [M]. In L. Berkowitz (ed.), Advances in Experimental Social Psychology. Orlando: FLAcademic Press, PP: 123205(1986)

[19] D.G. Gregg, S. Walczak. Dressing your online auction business for success: An experiment comparing two eBay businesses[J]. MIS Quarterly, 32(3): 653-670(2008)

[20] Bas, P.A. Pavlou. Evidence of the effect of trust building technology in electronic markets: price premiums and buyer behavior [J]. MIS Quarterly, 26(3): 243-268(2002)

[21] S. Tadelis, F. Zettelmeyer, F. Zettelmeyer. The Effect of Information on Auction Outcomes: A Large Scale Field Experiment [J]. General Information(2010)

[22] W. Song, L.H. Han. Influence Factor Analysis of Lending Willingness in P2P Online Lending[J]. Journal of Southwest Minzu University(Natural Science Edition), 39(5):795-799(2013) (In Chinese)

[23] E. Martina, Greiner, Hui Wang. Building Consumer-to-Consumer Trust in E-Finance Marketplaces: An Empirical Analysis [J]. International Journal of Electronic Commerce, 15(2): 105-136(20102011) 